\title{
TRANSITION TOWARDS TRANSRADIAL APPROACH IMPROVES OUTCOMES OF ACUTE MYOCARDIAL INFARCTION PCI
}

\author{
Oliver Kalpak ${ }^{1}$, Donco Donev², Hristo Pejkov${ }^{1}$, Slobodan Antov ${ }^{1}$, Gjorgji Kalpak ${ }^{3}$, Sasko Kedev ${ }^{1}$ \\ ${ }^{1}$ University Clinic of Cardiology, Medical Faculty, University of Ss. Cyril and Methodius, Skopje, Macedonia \\ ${ }^{2}$ Institute of Social Medicine, Medical Faculty, University of Ss. Cyril and Methodius, Skopje, Macedonia \\ ${ }^{3}$ Medical Faculty, Ss. Cyril and Methodius University, Skopje, R. Macedonia
}

Corresponding author: Oliver Kalpak. University Clinic of Cardiology, Mother Theresa 17, Skopje 1000, Macedonia, phone: +38970270923, e-mail: kalpakoliver@gmail.com

\section{ABSTRACT}

Introduction and aim: Transradial (TRA) instead of transfemoral (TFA) approach strategy has been presented in research literature as superior access strategy especially for acute ST elevation myocardial infarction (STEMI) primary percutaneous coronary intervention (PCI). There is a paucity of registry-based data of outcomes from default TRA strategy compared to TFA.

Materials and methods: All-comers STEMI PCI institutional Registry identified 1808 consecutive patients in time-frame of 40 months from 2007 to 2010, without making any exclusions. Moreover, we applied Propensity Score Matching (PSM) to replace randomization, address the potential confounding and selection bias. PSM derived 565 congruent pairs of patients from the groups.

Results: After 30 days the primary composite endpoint of major adverse cardiovascular events (MACE) was in favor of TRA $6.5 \%$ vs. $12.4 \%$ in TFA group, simultaneously secondary endpoints of death in TRA with rate of $4.8 \%$ and with rate of $10.1 \%$ in TFA. Moreover, the rate of major access related bleeding was $1.1 \%$ in TRA vs. $8.5 \%$ in TFA, in contrast the major non-access related bleeding was $1.8 \%$ and $2.4 \%$ respectively showed no significant difference. One year Kaplan Meier survival plots were in favor of TRA.

Conclusions: Default transradial access strategy is associated with improved STEMI PCI outcomes.

Key words: TRA, TFA, STEMI, acute myocardial infarction PCI, outcomes

\section{INTRODUCTION}

Acute myocardial infarction is established as the most common cause of death in the developed world and in the most of developing countries. Therefore, a change in treatment that could potentially reduce the mortality is of great professional and scientific importance [1]. Many studies have shown that urgent percutaneous coronary intervention (PCI) in the acute phase of the blocked artery in the first hours of the symptoms significantly reduces mortality. Consequently, PCI represents the optimal therapeutic strategy that is continuously being evolved and developed in order to reduce mortality and improve outcomes $[2,3]$. The official definition for acute myocardial infarction includes the changes in the morphology of the ECG showing ST-segment elevation, making the utilized STEMI acronym, which will be used in this publication.

We are witnessing significant advances and accelerated progress in science, pharmacology, medical practice and methodology in the field of interventional cardiology over the past decade, 
hence improving the outcomes and reducing the mortality in STEMI patients treated with PCI. Increased aggressive use of high-dose anticoagulation and antiplatelet treatment in STEMI patients in favor of increasing perfusion in the thrombogenic infarct lesion became a commonplace practice and is supported in several studies [4]. However, this treatment carries greater risk of minor and major bleeding events $[5,6]$. Bleeding complications in STEMI in turn have a strong association with increased mortality, since we usually discontinue the anticoagulation treatment to control bleeding. Furthermore, the blood recovery with allogenic transfusion of blood and blood components involves the increased risk of clot formation which in turn makes the treated infarct lesion susceptible to occlusion. Thus, a seemingly minor bleeding event along with discontinued anticoagulation can make a form of a vicious circle which contributes to the overall mortality of the intervention. Therefore, the effort of reduce bleeding leads to improved outcomes and reduced mortality in STEMI PCI patients [6].

The incidence rates of bleeding events are mainly influenced by the medication regimen as well as the arterial approach. While the anticoagulation regimen is required to prevent major complications, the arterial approach becomes the focus to reduce bleeding. In light of this, a pragmatic idea has surfaced to use the smaller more superficial radial artery versus the larger and less accessible femoral artery $[7,8]$.

There is a paucity of data in the literature concerning registry-based research that includes an unselected study population of patients with STEMI treated with transradial PCI as the primary access strategy. These are randomized controlled studies conducted with selected study population suitable for the alternative transradial approach with exclusion of the elderly patients, patients with pre-existing comorbidities and difficult clinical presentation [9]. Meaningful differences exist between mortality rates in randomized studies on selected study population and studies based on unselected registry done with statistical analysis on all patients; i.e. "all comers". Registry based studies report higher mortality rate versus randomized selected studies where the patients with high number of comorbidities are excluded $[9,-11]$.

Without timely intervention and reperfusion, the mortality in STEMI patients in the first 30 days is $30 \%$ to $50 \%$, while in the first year the mortality rate goes up to $70 \%$. Timely reperfusion, within the 12 hours of the first occurrence of the symptoms significantly improves these results. The registry-based studies report early mortality rates of $3.6 \%$ to $13 \%$, while in the first year the mortality goes up to $18 \%$. In the randomized selected studies the mortality rate ranges from $1.7 \%$ to $5.3 \%$ in the first month $[11,-13]$.

In the daily clinical practice, we do not choose the STEMI patients we intervene. Patients with pre-existing comorbidities, obese patients and elderly patients are usually the patient population where PCI intervention would prove to be the only life-saving procedure. The advantage of registry based study is that it includes all comers that have a STEMI PCI which reflects real life practice. There are few registry-based studies that report on nearly one hundred percent radial approach that is the current practice of our Clinic. Few publications have shown reduced mortality with experienced operators in centers with high TRA volume [11, 12,]. Therefore, as being an experienced TRA center we analyzed the success of the change towards TRA access strategy. In recent years in our intervention center there has been a significant shift in access strategy to near 100\% transradial approach, achieving high volume of interventions per year, making our operators with over 400 TRA PCI per year highly experienced. Currently, the transfemoral access strategy, at our institution remains only the alternative approach used in extremely rare cases [7].

The radial strategy poses as a technical challenge and requires extensive training and operator proficiency, particularly in patients with STEMI. In order to evaluate if the same operators can achieve better patient outcomes with the change of the access strategy, we compared TRA and TFA PCI groups in STEMI patients. We included all STEMI patients in our registry treated with TRA or TFA PCI during 40-month period without making any exclusions based on age or comorbidities. Moreover, in our data analysis we applied propensity score matching as a score equalizer of congruent pairs to reduce confounding amid fewer TFA cases. The scoring is based on patient baseline characteristics and compared one versus one in each of the groups [14]. We compared the two groups before and after the Propensity Score Matching.

\section{AIM OF THE STUDY}

The aim of this study is to assess and quantify the outcomes of PCI in STEMI patients with change in access strategy from transfemoral to 
transradial approach. Consequently, we compared the hard clinical outcomes between the two groups.

1. Assessing the rate of major cardiovascular event (MACE).

2. Rate of mortality in both groups.

3. Determining the association between bleeding and MACE.

4. Does the radial approach offer improvement in outcomes versus the femoral access strategy?

\section{MATERIALS AND METHODS}

To achieve the set goals, we collected data from our cardiology clinic registry software starting from October 2007 until the end of December 2010. We registered a total of 1808 STEMI patients with acute phase STEMI PCI. Based on the access strategy we identified two groups, TFA group with 646 patients, and TRA group with 1162 patients. Furthermore, we used the Propensity Score Matching method and identified 565 congruent pairs in both groups [14]. The gathered data and procedures used for this study are entirely in accordance with the official standards of our clinic and fall under constant supervision by our expert collegium. The choice for the arterial access strategy was made by the interventional cardiologist in accordance to the existing clinical practice at our clinic. The data used in our study are open for audit and evaluation to our health administration and national health fund.

All patients meet the following criteria:

Criteria for inclusion: 1. Intervention within the first 12 hours from the occurrence of chest pain symptom, 2. ST-elevation of at least $1 \mathrm{~mm}$ in two leads. 3. Absence of contraindication to complete anticoagulation and antiplatelet treatment.

Criteria for exclusion: 1. Refusing treatment, i.e. not signing the consent form in the acute phase period, 2. Ruling out the diagnosis of acute myocardial infarction. 3. Current bleeding or bleeding diathesis. 4. Fibrinolytic therapy before the intervention.

The Propensity Score Matching was done using significant baseline characteristics and clinical presentation factors differentiating between the two groups. The pairs are matches based on scores on the following variables: age, sex diabetes, hypertension, hyperlipidemia, family history, tobacco habits, previous STEMI, previous PCI or $\mathrm{CABG}$, previous stroke, cardiogenic shock at presentation, multiple coronary disease, and time from first symptom to first medical contact. Pro- pensity score matching method is proposed to be used in registry-based studies as a substitute to randomization [14].

\section{DEFINITIONS}

Acute myocardial infarction or STEMI is a syndrome of chest pain, electrocardiographic ST-elevation followed by dynamics of laboratory biomarkers due to myocardial necrosis. The myocardial ischemia changes the electrical potential of the heart muscle with initial ST-elevation of at least $1 \mathrm{~mm}$ in two leads which evolves over time. Persistent severe chest pain marks the beginning of the 12-hour time frame which a PCI procedure should be performed to save the reversibly damaged myocardium $[11,-13]$. The escalation and dynamics of the specific biomarkers is also part of the universal definition of acute myocardial infarction occurring in all patients from our register.

The percutaneous coronary intervention was a standard procedure well defined and without any difference regarding chosen arterial access. The focus of our study is the choice of the percutaneous arterial access site. Identical percutaneous sheath introducer set is used in TRA and TFA groups. The access site preparation and puncture technique is performed equally in both groups according to the modified Seldinger technique $[12,15]$.

Anticoagulation and antiplatelet treatment during the procedures in both groups with same anticoagulation and antiplatelet guidelines were followed by the operators. In the acute phase of STEMI we use a default anticoagulation and antiplatelet regimen standardized per the weight of the patient. Namely, according to established standards, before the intervention the patients are treated with intravenous bolus of unfractionated heparin (70-100 IU / kg) usually amounting to 5-10 thousand units. Subsequently, the patients are treated with antiplatelet dose of aspirin (acetylsalicylic acid $300 \mathrm{mg}$ ) and clopidogrel (600mg), which is followed by a sustainment regimen of dual antiplatelet therapy [16].

Hemostasis. The process of safely stopping the bleeding at the arterial access, using with compression technique, marks the most differentiating matter between the groups. The radial artery is more available for compression due to its superficial and small anatomy relative to the femoral artery. The percutaneous femoral sheath introducer is removed 4 hours after the heparin bolus, or 4-6 hours after the intervention, while 
the patient is immobilized. After the introducer removal, manual compression was made at the access site for 15-20 minutes, which is followed by a 4-hour weight compression. During the TFA hemostasis process the patient has limited mobility and must rest with staying in bed at least 6 hours after the introducer sheath removal (up to 10 hours if repeated bleeding occurs). The radial hemostasis procedure involves introducer sheath removal with a specific compression TR band placement which is inflated to pressurize the arterial access site, after which it gradually deflates over the next 2 hours, removed completely after 4 hours. In case of repeated bleeding the band is inflated for additional two hours. During this time the patients have no limited mobility. The TR compression band is inflated with $13-15 \mathrm{ml}$ of air in a plastic balloon directly above the puncture site $[11,17]$.

Main clinical events. The quality of the procedure between the two groups is determined with comparison of the main clinical events: cumulative major adverse cardiovascular events MACE, mortality, bleeding complications, within first 30 days and the one year follow-up after the intervention.

Primary endpoint: Major adverse cardiovascular events MACE, representing a composite point that includes death, repeated myocardial infarction, stroke, major bleeding that can be related or not to the artery access and repeated target vessel revascularization.

Secondary endpoints: Death as an outcome regardless of the cause. Stroke is defined as a neurological deficit lasting more than 24 hours suggesting a vascular etiology. Bleeding classification: In order to produce understandable and comparable results with other studies the Bleeding Academic Research Classification BARC was used to define Major bleed. Any Bleed of BARC grade 3 and more was considered major [18]. Access-related Major bleeding event: Represents a bleeding hematoma more than 15 centimeters diameter around the puncture site or any bleeding that requires erythrocyte transfusion, vascular surgery or PCI, anticoagulation and antiplatelet treatment disruption. The said bleeding events related to access site mark a type 3 or more according to BARC classification [18]. No-access related Major bleeding: includes intraperitoneal, intracranial, gastric bleeding as well as the BARC classification with type 3 or more, but unrelated to arterial access [18]. Minor access-related bleeding is defined as occurrence of hematoma up to 15 centimeters in diameter around the access site, without significant decrease in hemoglobin and hematocrit. The BARC classifies this as type 1 or type 2 bleeding [18].

\section{STATISTICAL ANALYSIS}

The numerical variables are expressed in values of frequency or represented as a percentage, the said values are medians taken from the minimum and maximum values that did not fit in the symmetric normal distribution and consequently are compared to the student t-test. Categorical variables are presented in terms of frequency or percentage and compared with Pearson's chisquared test and Fisher's exact test. The distribution of the basic demographic characteristics was compared in order to examine the concordance of the studied groups. Furthermore, unselected registry-based cohort was used with consecutively treated patients where the data are subsequently compared and equalized with using the Propensity Score Matching method. Additionally, this method replaces randomization which provides better objectivity, with patients matching $1: 1$ with the nearest score value, with caliper of 0.05 for inclusion and 0.10 for exclusion. According to Hosmer-Lemeshow test for goodness of fit test for logistic regression checking eligibility of the matched pairs we identified 565 patients in each of the groups. Dichotomous variables for the end outcomes of the main points will be compared with Pearson's chi-square test. The Webster-Willcox method will determine the proportion of chance (OR odds ratio) in the interval (CI confidence interval 95\%) expressing the resulting statistical significance for the level of probability with twotailed P-value. All P-values less than 0.05 are considered statistically significant. The time-to-event curves are shown with the Kaplan-Meyer method and compared with Mantel-Cox log-rank analysis for statistical significance. Statistical analysis was performed using the statistical software package SPSS PASW 19 [14, 19, 20].

\section{RESULTS}

The values of the matched and unmatched cohorts are outlined in the respective tables with 1130 in the matched cohort and 1808 in the unmatched cohort. The total number of STEMI patients is 1808 patients divided in TFA group with 646 and TRA group with 1162 patients. With the PSM we get 565 pairs who were scored and 
Table 1. Whole Registry cohort before matching and after Propensity Score Matching

\begin{tabular}{|l|c|c|c|c|c|c|}
\hline \multirow{2}{*}{} & \multicolumn{2}{|c|}{ Before Propensity Score Matching } & \multicolumn{3}{c|}{ After Propensity Score Matching } \\
N=1130
\end{tabular}

$\mathrm{TRA}=$ trans-radial approach, $\mathrm{TFA}=$ trans-femoral approach, $\mathrm{CAD}=$ coronary artery disease, $\mathrm{PCI}=$ percutaneous coronary intervention, $\mathrm{MI}=$ myocardial infarction, $\mathrm{CVI}=$ cerebrovascular insult, $\mathrm{CHF}=$ chronic heart failure

matched between the two groups and adjusted cohort was 1130 patients.

Before PSM there were some baseline differences and confounding factors, particularly cardiogenic shock or similar difficult clinical presentation, with potential to introduce bias. Using Propensity Score Matching gives a potential reduction in confounding and selection bias making the matched pairs comparison the right method choice in absence of randomized selection. Propensity score matching acts as an equalizer of any differences that existed in the two groups. After Propensity Score Matching baseline characteristics and the risk factors were equalized between the two groups and this potential was addressed.
Angiographic variables were not included in the scoring algorithm as they are part of our study research, and, conversely, they showed no statistically significant trends when comparing both groups. Moreover, infarct related-culprit artery was in similar proportions in both groups. Namely at TRA group culprit vessel was LAD in $46.2 \%$, LCX in $13.1 \%$, RCA in $40.7 \%$, LM in $1.4 \%$. Similar to this LAD was culprit in $49.2 \%$ patients, LCX in $12.6 \%$, RCA in $38.1 \%$ and LM in $1.1 \%$ of the patients in TFA group. Additionally clinically important intervention related factors showed no statistically significant difference among the groups, The success rate of PCI defined as achieved TIMI 3 flow or complete flow restoration of culprit ar-

Table 2. Equal pre-procedural and in-procedure time as well as procedure success

\begin{tabular}{|l|c|c|c|}
\hline & $\begin{array}{c}\text { TRA } \\
(\mathbf{N}=\mathbf{5 6 5})\end{array}$ & $\begin{array}{c}\text { TFA } \\
(\mathbf{N}=\mathbf{5 6 5})\end{array}$ & P \\
\hline Time frame in minutes \\
\hline Symptom to FMC & $106(22-920)$ & $104(15-950)$ & 0.748 \\
\hline Door to balloon & $54.7(10-255)$ & $52.1(10-260)$ & 0.304 \\
\hline Procedural time & $39.3 .4 \pm 16.3$ & $38.1 \pm 10.7$ & 0.415 \\
\hline Fluoroscopy time & $9.8 \pm 5.5$ & $9.5 \pm 6.5$ & 0.561 \\
\hline Reperfusion parameter & \multicolumn{4}{|l}{} \\
\hline Procedural success & $552(97.7 \%)$ & $553(97.9 \%)$ & 0.843 \\
\hline Baseline TIMI flow 0 & $436(77.2 \%)$ & $441(78.1 \%)$ & 0.329 \\
\hline Final TIMI flow 3 & $540(95.6 \%)$ & $538(95.2 \%)$ & 0.815 \\
\hline
\end{tabular}

$\mathrm{FMC}=$ first medical contact, Procedure success $=$ flow restored to TIMI 2 or TIMI 3 flow grade, $\mathrm{TIMI}=$ thrombolysis in myocardial infarction study group; time in minutes (range in bracket) 
Table 3. Outcomes in Propensity score matched cohort and without adjustment

\begin{tabular}{|c|c|c|c|c|c|c|c|c|}
\hline & \multicolumn{4}{|c|}{ Without PSM } & \multicolumn{4}{|c|}{ With PSM adjustment } \\
\hline & $\begin{array}{c}\text { TRA } \\
(\mathrm{N}=1162)\end{array}$ & $\begin{array}{c}\text { TFA } \\
(\mathrm{N}=646)\end{array}$ & $\begin{array}{c}\text { OR } \\
(95 \% \mathrm{CI})\end{array}$ & $\mathbf{P}$ & $\begin{array}{c}\text { TRA } \\
(\mathbf{N}=565)\end{array}$ & $\begin{array}{c}\text { TFA } \\
(\mathrm{N}=565)\end{array}$ & $\begin{array}{c}\text { OR } \\
(95 \% \mathrm{CI})\end{array}$ & $\mathbf{P}$ \\
\hline \multicolumn{9}{|l|}{ Primary endpoint } \\
\hline MACE at 30 days & $\begin{array}{c}85 \\
(7.3 \%) \\
\end{array}$ & $\begin{array}{c}81 \\
(12.5 \%) \\
\end{array}$ & $\begin{array}{c}0.55 \\
(0.39-0.76) \\
\end{array}$ & 0.001 & $\begin{array}{c}37 \\
(6.5 \%) \\
\end{array}$ & $\begin{array}{c}70 \\
(12.4 \%) \\
\end{array}$ & $\begin{array}{c}0.49 \\
(0.33-0.75) \\
\end{array}$ & 0.001 \\
\hline MACE at 1 year & $\begin{array}{c}135 \\
(12 \%) \\
\end{array}$ & $\begin{array}{c}130 \\
(20 \%) \\
\end{array}$ & $\begin{array}{c}0.52 \\
(0.40-0.68) \\
\end{array}$ & 0.001 & $\begin{array}{c}62 \\
(11.0 \%) \\
\end{array}$ & $\begin{array}{c}110 \\
(19.5 \%) \\
\end{array}$ & $\begin{array}{c}0.51 \\
(0.36-0.71) \\
\end{array}$ & 0.001 \\
\hline \multicolumn{9}{|l|}{ Secondary endpoints } \\
\hline Death at 30 days & $\begin{array}{c}60 \\
(5.2 \%) \\
\end{array}$ & $\begin{array}{c}68 \\
(10.5 \%) \\
\end{array}$ & $\begin{array}{c}0.46 \\
(0.32-0.66) \\
\end{array}$ & 0.001 & $\begin{array}{c}27 \\
(4.8 \%)\end{array}$ & $\begin{array}{c}57 \\
(10.1 \%)\end{array}$ & $\begin{array}{c}0.45 \\
(0.28-0.72)\end{array}$ & 0.001 \\
\hline Death at 1 year & $\begin{array}{c}80 \\
(7 \%) \\
\end{array}$ & $\begin{array}{c}74 \\
(11 \%) \\
\end{array}$ & $\begin{array}{c}0.57 \\
(0.41-0.79) \\
\end{array}$ & 0.001 & $\begin{array}{c}37 \\
(6.5 \%) \\
\end{array}$ & $\begin{array}{c}61 \\
(10.8 \%) \\
\end{array}$ & $\begin{array}{c}0.58 \\
(0.38-0.88) \\
\end{array}$ & 0.001 \\
\hline $\begin{array}{l}\text { Access related } \\
\text { Major bleeding }\end{array}$ & $\begin{array}{c}11 \\
(0.9 \%)\end{array}$ & $\begin{array}{c}53 \\
(8.2 \%) \\
\end{array}$ & $\begin{array}{c}0.11 \\
(0.05-0.20) \\
\end{array}$ & 0.001 & $\begin{array}{c}6 \\
(1.1 \%) \\
\end{array}$ & $\begin{array}{c}48 \\
(8.5 \%) \\
\end{array}$ & $\begin{array}{c}0.12 \\
(0.05-0.27) \\
\end{array}$ & 0.000 \\
\hline $\begin{array}{l}\text { Non access related } \\
\text { Major bleeding }\end{array}$ & $\begin{array}{c}13 \\
(1.2 \%)\end{array}$ & $\begin{array}{c}15 \\
(2.3 \%) \\
\end{array}$ & $\begin{array}{c}0.24 \\
(0.12-0.46) \\
\end{array}$ & 0.001 & $\begin{array}{c}10 \\
(1.8 \%)\end{array}$ & $\begin{array}{c}13 \\
(2.4 \%)\end{array}$ & $\begin{array}{c}0.78 \\
(0.28-1.22) \\
\end{array}$ & 0.301 \\
\hline
\end{tabular}

$\mathrm{MACE}=$ major adverse cardiovascular event, $\mathrm{OR}=$ odds ratio, $\mathrm{CI}=$ confidence interval.

tery, and the presence of multivessel coronary artery disease show no difference between groups. The possible mortality rate denominator remains to be used access strategy.

Time variables significant for STEMI intervention were not different between the groups. The radial access does not prolong the door to balloon time; which represents the time period from hospital admission to balloon placement in the infarct artery. Moreover, TRA access strategy does not increase the radiation exposure time, nor the time needed to complete the intervention. We did not find statistically significant exposure during real time x-ray fluoroscopy between the both groups.

Differences in favor of TRA versus TFA group exist in primary endpoints regarding significant clinical outcomes as MACE rate. The major cardiovascular events within 30 days are more common with $12.4 \%$ in TFA versus $6.5 \%$ in the TRA group. This difference does not diminish over the 1 year follow-up.

After 30-day follow up we found a significant difference in the mortality of $4.8 \%$ versus $10.1 \%$ in TFA. Significant difference is identified in access-related major bleeding events with $1.1 \%$ in TRA versus $8.5 \%$ in the TFA group.
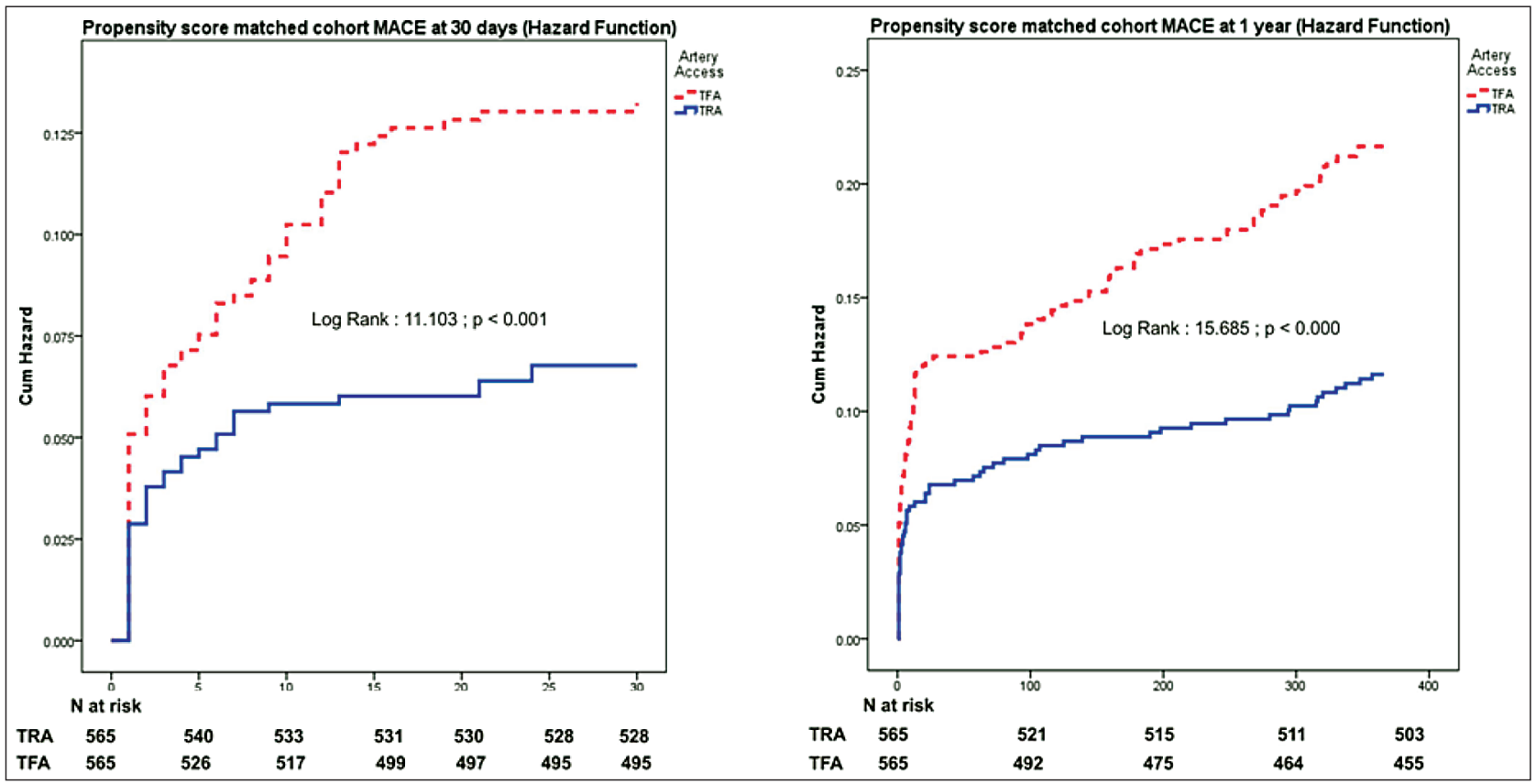

Figure 1. MACE Kaplan Meier curves divided early and persistently 
The difference remained significant early and even after follow up as we illustrated by the Kaplan Mayer survival curves and Mantel-Cox log rank score, in first thirty days. In the 30-day curves for MACE gradually separates in the first 10 days, with subsequent parallel separated curves formation between the groups, showing a statistically significant improved rate in the radial access group and significant primary endpoint difference. Mortality rate starts to diverge in the first 2 days with a continuous increase favoring the TRA group.

\section{DISCUSSION}

Our study represents a large registry based study sample from default TRA center analyzing the impact of arterial access on main clinical outcomes from PCI in STEMI. The data analysis supplementation with scoring and matching the congruent pairs of both groups using the Propensity Score Matching method reduces the potential confounding and selection bias, particularly in absence of randomization. The analysis resulted in several important findings.

1. The data from the registry showed that the transradial approach is associated with lower rate of major adverse events, lower major bleeding event rates and lower mortality rate when compared with the transfemoral access group for PCI in STEMI. Additionally, the TRA group showed significantly lower access-related bleeding rate.

2. After Propensity Score Matching the results from the data analysis are consistent with the overall registry study sample comparison. Certain variation in the percentages can be found, however all results follow the same statistical trend in favor of the TRA group. With the matching method, we further solidified the results from the unmatched data comparison.

3. After subgroup division, the radial approach persists as an independent predictor of survival and lack of MACE after 30 day and 1 year follow up period. We did not find, angiographic success difference between groups, but yet there was mortality benefit in the TRA arm. The possible mortality rate denominator remains to be access strategy as the only group difference.

The main advantage of the transradial approach (TRA) is the reduced access-site compli- cations due to its smaller and more superficial anatomy, making it easily compressible which further reduces the number of bleeding complication events and allows for patient mobility. In addition, the elegant change in access strategy allows for adequate use of anticoagulation regimen which reduces coronary mortality and morbidity $[7,9]$. Contrarily, femoral arterial cannulation carries a significant risk for access-site bleeding complications such as hematomas and pseudoaneurysms, often accompanied with painful presentation with prolonged patient immobility and increased hospital stay $[7,10]$.

The main disadvantage associated with the transradial approach is the steep learning curve. Manipulating with guidewires and catheters through the often tortuous radial and subclavian arteries to reach the aortic arch and coronary arteries pose a technical challenge and require operator proficiency. However, studies show that experienced high volume transradial operators have improved outcomes versus low volume centers and operators $[7,9,-11]$.

Our findings of TRA association with lower MACE rates are consistent with several published randomized and non-randomized studies. The results of the early and late outcomes are comparable with other international high impact studies. Namely, Herington et al. 2009 have showed findings of MACE rate of $7.3 \%$ in the 571 patient TRA group compared to $13.3 \%$ in the 480 patients TFA group. Similarly, our findings show MACE rate of $6.9 \%$ in the TRA and $11.5 \%$ in the TFA group $(p<0.01)$, respectively [21]. The results of the first major randomized trial RIFLE STEACS (Radial vs. Femoral Investigation in ST Elevation Acute Coronary Syndrome) with study sample 1001 patients, making 500 TRA vs. 501 TFA patients group comparison, show radial access strategy association with lower MACE and reduced mortality relative to the TFA group with 30 day mortality of $5.2 \%$ vs. $9.2 \% 95 \%$ CI; OR $=2.4 ; 0.8-7.3 ; \mathrm{p}=0.02[22]$.

The mentioned findings show a mortality reduction with reduced clinically significant bleeding rates which confirms the relationship between the mortality and major bleeding events associated with PCI access strategy for STEMI patients. Moreover, our study showed an even more significant difference in 30-day mortality with TRA $4.8 \%$ vs. TFA $10.1 \%$ OR $=: 0.45 ; 95 \%$ $\mathrm{CI}=0.28-0.72 ; \mathrm{p}<0.001$, respectively.

Similar findings are shown in the selective randomized study RIVAL (Radial versus femoral 
access for coronary angiography and intervention in patients with acute coronary syndromes). Their study reports a mortality rate of $1.3 \%$ in TFA versus $3.2 \%$ in TFA strategy $(\mathrm{OR}=0.5895 \% \mathrm{CI}=$ $0.29-0.81 ; \mathrm{p}<0.01)$. These results are with lower rates, however with same proportion compared to our study results $[23,24]$.

Recent meta-analysis comprised of 9 randomized controlled studies including cumulatively 2977 patients show TRA association of $47 \%$ mortality reduction and 38\% major cardiovascular events reduction for PCI in STEMI. Similarly, the American registry analysis NCDR (North American National Cardiovascular Data Registry, Cath-PCI Registry) with 90,879 patients show that TRA is independently associated with intrahospital mortality reduction $(\mathrm{OR}=0.76 ; 95 \% \mathrm{CI}=0.57$ $0.99)$ and bleeding $(\mathrm{OR}=062 ; 95 \% \mathrm{CI}=0.53-0.72)$. In addition, the American registry study showed $85 \%$ of TFA access for PCI in STEMI quite lower than almost complete radial in our registry past few years. The authors advocate the promotion of TRA as default strategy to reduce complication and improve outcomes [25]. Moreover, the British registry with 46,128 patients from which $30 \%$ are in the TRA group, also suggest an independent association of radial strategy with lower mortality $(\mathrm{HR}=0.75 ; \mathrm{p}<0.05)$, with reduced MACE $(\mathrm{HR}=$ $0.73 ; \mathrm{p}<0.05)$ and access-related major bleeding events $(\mathrm{HR}=0.37 ; \mathrm{p}<0.01)$ [26].

The associated mechanisms of major bleeding complications with the mortality rate are explained with the necessity of disruption of the anticoagulation and antiplatelet treatment to control the bleeding during the PCI in STEMI. Stopping the standard anticoagulation during the procedure carries the risk of repeated myocardial ischemia and intravascular thrombosis in the intervened infarct coronary artery. This is the reason why even a minor bleeding can impact the procedure outcome. Furthermore, the local hematoma in the groin occurring in the transfemoral approach can activate certain prothrombogenic pathways increasing the risk of thrombus formation. In addition, the prolonged immobility, which patients must endure in the TFA approach, can have a negative impact which can increase overall procedure mortality $[25,26]$. These mechanisms need to be further evaluated with specifically designed studies and larger study sample.

Study limitations: Our registry based study design differs in the accuracy associated with the randomized clinical trials, however using the Propensity Score Matching method and selecting the congruent pairs from the both groups, with their subsequent comparison, increases the validity of our data analysis. Using this method, we equalize the variables between the both groups reducing the potential confounding and selection bias. The final results show consistent findings with our primary data analysis and are comparable with other registry based and randomized clinical trial studies. After score matching our study sample was 1130 with mortality rate of $4 \%$ in TRA and $8 \%$ in the TFA group. Calculating the statistical power of the trial we found that study sample of 3000 patients will be needed to detect mortality benefit larger than $25 \%$. In order to achieve greater statistical power in detecting the TRA mortality benefit further investigation and larger study samples is needed.

\section{CONCLUSION}

The transition from femoral to radial access strategy for PCI treatment in STEMI patients is safer and can contribute to outcome improvement. The transradial access is associated with reduced access site related major bleeding and reduced mortality. These results should be confirmed with further research and a larger study sample with comparison of the PCI radial versus femoral access strategy outcomes in acute myocardial infarction.

\section{REFERENCES}

1. Cannon CP, Braunwald $\mathrm{E}, \mathrm{McCabe} \mathrm{CH}$, et al. The Thrombolysis in Myocardial Infarction (TIMI) trials: the first decade. J Interv Cardiol. 1995; 8(2):117-135.

2. Bahit MC, Cannon CP, Antman EM, et al. Direct comparison of characteristics, treatment, and outcomes of patients enrolled versus patients not enrolled in clinical trial at centers participating in the TIMI 9 Trial and TIMI 9 Registry. Am Heart J. 2003; 145: 109-117.

3. Hartzler GO, Rutherford BD, Mc Conahy DR, et all. : Percutaneous transluminal coronary angioplasty with and without thrombolytic therapy for treatment of acute myocardial infarction. Am Heart J 1983, 106: 965-973

4. Kaev M, Kalpak O,: Pharmacological Treatment of Acute Myocardial Infarction: , Mak Med Pregled No 44, 1-135, Skopje 2000

5. Stone GW. Stenting and IIb/IIIa receptor blockade in acute myocardial infarction: an introduction to the CADILLAC trial. J Invas Cardiol 1998;10(suppl B):36B-47B 
6. Mehran R, Pocock S, Nikolsky E, et al. Impact of bleeding on mortality after percutaneous coronary intervention results from a patient-levelpooled analysis of the REPLACE-2 (Randomized Evaluation of PCI Linking Angiomax to Reduced Clinical Events), ACUITY (Acute Catheterization and Urgent Intervention Triage Strategy), and HORIZONS-AMI (Harmonizing Outcomes With Revascularization and Stents in Acute Myocardial Infarction) trials. J Am Coll CardiolIntv 2011; 4:654-64.

7. Kiemeneij F, Laarman GJ, Odekerken D, et al. A randomized comparison of percutaneous transluminal coronary angioplasty by the radial, brachial and femoral approaches: The ACCESS study. J Am Coll Cardiol 1997; 29:1269-1275.

8. Kedev S. Radial or femoral approach for patients with acute coronary syndrome. Cardiology International, 2012:45-49.

9. Mamas MA, Ratib K, Routledge H, et al. Influence of arterial access site selection on outcomes in primary percutaneous coronary intervention. Are the results of randomized trials achievable in clinical practice? JACC Cardiovasc Interv. 2013;6(7):698-706

10. Doyle BJ, Ting HH, Bell MR, et al. Major femoral bleeding complications after percutaneous coronary intervention: incidence, predictors, and impact on long-term survival among 17,901 patients treated at the Mayo Clinic from 1994 to 2005. JACC Cardiovasc Interv.2008;1(2):202-209

11. Hamon M, Pristipino C, Di Mario C, et al. Consensus document on the radial approach in percutaneous cardiovascular interventions: position paper by the EAPCI and Working Groups on Acute Cardiac Care and Thrombosis of the European Society of Cardiology. EuroIntervention. 2013; 8(11):1242-1251.

12. O'Gara PT, Kushner FG, Ascheim DD, et al. 2013 ACCF/AHAguideline for the management of ST-elevation myocardial infarction: report of the American College ofCardiologyFoundation/AmericanHeart Association Task Force on Practice Guidelines. J Am CollCardiol 2013;61:e78-140

13. Bernat I, Horak D, Stasek J, Mates M, et al. STEMI-RADIAL: a prospective randomized trial of radial vs. femoral access in patients with ST-segment elevation myocardial infarc- tion. Paper presented at: Transcatheter Cardiovascular Therapeutics (TCT) Scientific Symposium; October 26, 2012; Miami, FL.

14. Altman DG. Relation between several variables. In: Altman DG, ed. Practical statistics for medical research. London: Chapman and Hall; 1991. p. 325-61.

15. Popma JJ, Bashore TD. Qualitative and quantitative angiography. In: Topol E, editor. Textbook of interventional cardiology. Philadelphia: WB Saunders; 1994. p. 1052-68

16. Mehta SR, Tanguay JF, Eikelboom JW, et al. Double-dose versus standard-dose clopidogrel and high-dose versus low-dose aspirin in individuals undergoing percutaneous coronary intervention for acute coronary syndromes (CURRENT-OASIS 7): a randomized factorial trial. Lancet. 2010;376:1233-1243

17. Rao SV, Cohen MG, Kandzari DE, Bertrand OF, Gilchrist IC. The transradial approach to percutaneous coronary intervention: historical perspective, current concepts, and future directions. J Am Coll Cardiol2010; 55:2187-95.

18. Mehran R, Rao SV, Bhatt DL, et al. Standardized bleeding definitionsfor cardiovascular clinical trials: a consensus report from the BleedingAcademic Research Consortium. Circulation 2011;123:2736-47

19. Moher D, Dulberg S C, Wells G. Statistical Power, Sample Size, and Their Reporting in Randomized Controlled Trials. JAMA. 1994;272:122-124

20. Tushar Vijay Sakpal. Sample Size Estimation in Clinical Trial. PICR April-June 2010 Vol 1 Issue 2:67-69.

21. Hetherington S Let al. Primary percutaneous coronary intervention for acute ST-segment elevation myocardial infarction: changing patterns of vascular access, radial versus femoral artery. Heart 2009 95: 1612-1618

22. Romagnoli E, Biondi-Zoccai G, Sciahbasi A, et al. Radial versus femoral randomized investigation in ST-segment elevation acute coronary syndrome: the RIFLE-STEACS (Radial Versus Femoral Randomized Investigation in ST-Elevation Acute Coronary Syndrome) study. J Am Coll Cardiol 2012; 60:2481-9.

23. Jolly SS, Yusuf S, Cairns J, et al. Radial versus femoral access for coronary angiography and intervention in patients with acute coronary syndromes (RIVAL): a randomised, parallel group, multicentre trial. Lancet. 2011;377(9775):1409-1420 
24. Jolly SS, Amlani S, Hamon M, et al. Radial versus femoral access for coronary angiography or intervention and the impact on major bleeding and ischemic events: a systematic review and meta-analysis of randomized trials. Am Heart J. 2009;157:132-140

25. Rao SV, Ou FS, Wang TY, et al. Trends in the prevalence and outcomes of radial and femoral approaches to percutaneous coronary intervention: A report from the National Cardiovascular Data Registry. J Am Coll Cardiol Intv 2008; 1:379-386.

26. Mamas MA, Ratib K, Routledge H, et al. Influence of access site selection on PCI-related adverse events in patients with STEMI: meta- analysis of randomised controlled trials. Heart. 2012;98(4):303- 311

\title{
ТРАНЗИЦИЈАТА КОН ТРАНСРАДИЈАЛЕН ПРИСТАП ГО ПОДОБРУВА ИСХОДОТ ОД ИН- ТЕРВЕНЦИИТЕ ПРИ АКУТЕН МИОКАРДЕН ИНФАРКТ
}

\author{
Оливер Калпак ${ }^{1}$, Дончо Донев ${ }^{2}$, Христо Пејков ${ }^{1}$, Слободан Антов ${ }^{1}$, \\ Ѓорѓи Калпак ${ }^{3}$, Сашко Кедев ${ }^{1}$ \\ ${ }^{1}$ Универзитетска Клиника за Кардиологија, Медицински факултет, \\ Универзитет „Св. Кирил и Методиј“, Скопје, Македонија \\ ${ }^{2}$ Институт за социјална медицина, Медицински факултет, \\ Универзитет „Св. Кирил и Методиј“, Скопје, Македонија \\ ${ }^{3}$ Медицински факултет, Универзитет „Св. Кирил и Методиј“, Скопје, Македонија
}

\section{Резиме}

Вовед: Трансрадијалната (ТРА) наместо трансфеморалната (ТФА) стратегија за артериски пристап, е елегантна промена на пристапот која може да го подобри исходот при интервенцијата за акутниот миокарден инфаркт.

Цел: Детерминирање дали ТРА групата е подобра во поглед на мајорни кардиоваскуларни настани и морталитет наспроти ТФА групата.

Материјал и Методи: Анализиравме 1808 консекутивни пациенти од регистарот за интервенции на Клиниката, со интервенција при акутниот миокарден инфаркт со СТ елвација на електрокардиограмот (СТЕМИ) Ги компариравме според пристапот и тоа ТФА групата 646 со ТРА групата од 1162 пациенти. Извршивме скорирање според методата на Propensity Score Matching за да се елиминираат разликите о отсуствово на рандомизација по што се идентификуваа по 565 пациенти во секоја од групите. Ги компариравме клинички релевантните исходи, по следење од 30 дена и по едно годишно следење.

Резултати: По следење од 30 дена најдовме значајна разлика на стапката на мајорни кардиоваскуларни настани и тоа ТРА $6.5 \%$ наспроти $12.4 \%$ кај ТФА групата, стапката на морталитетот $4.8 \%$ наспроти $10.1 \%$ во пропорциите на појавување на мајорното крварење поврзано со пристапот $1.1 \%$ кај ТРА наспроти $8.5 \%$ кај ТФА групата. Разликата беше сигнификантна и по една година следење. Со кривите на преживување по Каплан Мајеровиот метод илустриравме статистички значајна разлика помеѓу групите во периодот на следење.

Заклучок: Трансрадијалната стратегија како рутински избор за артериски пристап е поврзана со подобар клинички исход при интервенцијата за акутен миокарден инфаркт.

Клучни зборови: ТРА, ТФА, СТЕМИ, Акутен миокарден инфаркт, перкутани коронарни интервенции, ПКИ 